\title{
Polyphenols and Flavonoids in Colombian Fruit and Vegetables - Applications and Benefits: A Review
}

\author{
Juan Carlos Carmona-Hernandez ${ }^{1,2, *}$, Laura Mariana Ceballos-López ${ }^{2}$, Clara Helena González-Correa ${ }^{3}$ \\ ${ }^{1}$ Grupo de Investigación Médica, Universidad de Manizales, Manizales (Caldas) Colombia \\ ${ }^{2}$ Grupo de Investigación Bioimpedancia Eléctrica, Universidad de Caldas, Manizales (Caldas) Colombia \\ ${ }^{3}$ Grupo de investigación en Nutrición, Metabolismo y Seguridad Alimentaria, Universidad de Caldas, Manizales (Caldas) Colombia \\ *Corresponding author: jucaca@umanizales.edu.co
}

\begin{abstract}
Fruits and vegetables are important sources of nutritional and therapeutic compounds. Polyphenols and flavonoids are plant secondary metabolites with several biological functions and multiple benefits for humans. Their general chemical characteristics, such as their structures and functional groups, are key to explain their variability and functionality. This review covers 21 Colombian fruits and vegetables containing different amount of polyphenols and flavonoids. They have several applications and offer various benefits, such as antioxidant, bactericidal, and anti-inflammatory activities. Nutritional contributions and therapeutic applications of polyphenols and flavonoids have been reported in multiple studies, and these phytochemicals can be incorporated into dietary products. It is feasible that further beneficial effects of these natural compounds may be discovered in fruits and vegetables found in several regions of Colombia.
\end{abstract}

Keywords: chemical characteristics, biological action, nutritional benefits

Cite This Article: Juan Carlos Carmona-Hernandez, Laura Mariana Ceballos-López, and Clara Helena González-Correa, "Polyphenols and Flavonoids in Colombian Fruit and Vegetables - Applications and Benefits: A Review." Journal of Food and Nutrition Research, vol. 6, no. 3 (2018): 176-181. doi: 10.12691/jfnr-6-3-6.

\section{Introduction}

Flavonoids are the most numerous types of polyphenolic phytochemicals. They are found in different parts of the plant and display different biological functions, as well as contributing to the colour of the plant [1]. Polyphenol molecules comprise several classes, and flavonoids are the most studied. The subgroups of flavonoids include stilbenes for example resveratrol, anthocyanins such as apigeninidin, and phenolic acids like caffeic acid. Polyphenols and flavonoids have different biochemical actions [2]. Flavonoids are antioxidants, anti-inflammatory compounds, and fat reducing agents $[3,4]$. Although these phytochemicals have multiple health benefits, their mechanisms of action are not completely clear, mainly due to their structural variability [5].

Health effects of polyphenols have attracted the attention of nutritionists and health professionals. In 1995, it was rare to see the term "flavonoids" in non-specialist books [5]. The first International Conference on Polyphenols and Health took place late in 2004, with the participation of researchers from more than 30 countries. It focused on advances in the understanding of polyphenol intake, and its effects on disease and health [5]. This review aims to survey polyphenols and flavonoids in Tropical and Amazonian dietary products found in Colombia. One fruitful research direction is the comparison of polyphenols and flavonoids in well-studied dietary products such as strawberries, red wine, nuts, grapes, olive oil, and apples.

\subsection{General Aspects}

Polyphenols are a heterogeneous group of molecules that share structural characteristics — they all have substituted benzene groups with hydroxyl and other functional groups. Flavonoids are the best defined polyphenolic subgroup found in human diet [1]. Flavonoids are aromatic heterocyclic compounds containing oxygen pigments and are widely distributed in plants. Flavonoids are constituents of most yellow, red and blue colours in plants and fruits [6]. Their structures comprise two phenyl groups labelled as A and B, joined by a pyran group represented by the letter $\mathrm{C}$. This cyclic structure forms a diphenylpyrane core expressed as C6-C3-C6 that is common to most flavonoids [1]. Figure 1 shows a general representation of a polyphenol with its functional groups.<smiles>COc1ccc(-c2oc3cc(O)cc(O)c3c(=O)c2O)cc1O</smiles>

Figure 1. General chemical representation of a polyphenol

Oxygen functional groups provide polarity to aromatic rings, the water solubility increasing as the number of 
oxygen substituents increases [7]. The functionality of polyphenols and flavonoids and their classification depends on functional groups present. Chemical groups found in polyphenols include hydroxyl, ketone, and carboxyl groups [8]. Most polyphenols in nature exist as glycosides which join to glucose or galactose. Within the flavonoid group, there are flavanol, flavone, flavanone, and anthocyanin subclasses [9].

\subsection{Biochemical Processes}

Polyphenols display pharmacological activities. They may act in vasodilation, as anticancer, anti-inflammatory, and bactericidal agents, as immune system stimulants, as antiallergenic, antiviral, and oestrogenic agents, and as lipoxygenase and xanthine oxidase inhibitors [10]. Epidemiological studies report that polyphenols may protect against bladder and lung cancer. There is also evidence that polyphenols are cardioprotective [10].

Several studies report that flavonoids have pro-oxidant activity $[11,12,13]$. They protect organisms and prevent damage to humans caused by oxidants such as UV radiation, environmental pollution, and chemical substances in food. [12]. It has been suggested that flavonoids are better antioxidants than vitamins, being efficient free radical regulators. This characteristic makes them beneficial in several nutritional and medical aspects $[14,15,16]$. Their free radical targets are hydroxyl and superoxide radicals, which are known to be very reactive in lipid peroxidation [13].

Flavonoids modify eicosanoid synthesis and prevent platelet aggregation, yielding antithrombotic effects and protecting low-density lipoproteins from becoming oxidized, thus preventing atheroma formation $[13,15]$. They also block tumour development and prevent angiogenesis, preventing the arrival of oxygen and nutrient at neo-tumour cells [17]. They also modulate oestrogenic reactions by attaching to receptors, lowering the risk of breast cancer. Several flavonoids can inhibit cytochrome P-450 dependent monooxygenases, playing a role in regulating the activation of carcinogens [17].

\section{Colombian Products as Sources of Different Polyphenol Types}

Multiple varieties of fruit grow in all regions of Colombia (South America) [18,19]. Different climates, geographical conditions, and water resources favour the cultivation and harvesting of local fruits and vegetables [19]. New studies are focusing on evaluating the biological activity of tropical and Amazonian fruits from Colombia.

The star fruit, or carambola, Averrhoa carambola (Oxalidaceae), develops in low and medium altitude tropical conditions (0-1,200 meters above sea level); it grows in several regions in Colombia (i.e. Valle del Cauca, Córdoba, Antioquia, Quindío, Tolima, Meta, and the Caribbean zone). Its optimum temperature is in the range 21 to $32^{\circ} \mathrm{C}$ [20]. The flesh of the carambola fruit is light yellow, crisp and juicy; its flavour varies from very acid to sweet. Apigenin is found in the pulp, and it exhibits anti-inflammatory and anti-tumour activities [21].

Zapote mamey (Pouteria sapota) originates from southern Mexico and northern Nicaragua. It can be found throughout Central America, the Caribbean, and northern South America. It is found at altitudes up to $1500 \mathrm{~m}$. This fruit contains catechin and has high antioxidant activity [22]. One study has found an inverse relationship between the consumption of zapote mamey and the incidence of cardiovascular diseases and cancer [23].

Wild cocoa or copoazú (Theobroma grandiflorum), is an exotic tropical fruit found in Peru, Colombia, Ecuador, and Brazil. Copoazú is cultivated in regions with annual average temperatures above $22^{\circ} \mathrm{C}$, rainfall above 1,500 $\mathrm{mm}$, and relative humidity above $75 \%$ [4]. Catechin is the major flavonoid in copoazú, and it provides antioxidant effects [3]. More examples of polyphenol sources are shown in Table 1, highlighting their biological functionality.

Table 1. Polyphenol sources and some of their biological actions

\begin{tabular}{|c|c|c|c|c|}
\hline$\#$ & Colombian source of polyphenols & Type or subclass & Biological action & Reference \\
\hline 1 & Acaí Euterpe oleracea & Flavonoids & Anti-inflammatory & {$[24,25]$} \\
\hline 2 & Albaricoque Ximenia americana & Flavonoids & Antioxidant & {$[26,27,28]$} \\
\hline 3 & Berenjena Solanum melongena & Anthocyanin & Antioxidant & {$[29,30,31]$} \\
\hline 4 & Borojó Borojoa patinoi & $\begin{array}{c}\text { Phenols } \\
\text { Flavonoids }\end{array}$ & $\begin{array}{c}\text { Antioxidant } \\
\text { Antimicrobial }\end{array}$ & {$[32,33]$} \\
\hline 5 & Capulí Prunus serótina & Anthocyanin & Antioxidant & [34] \\
\hline 6 & Chope Gustavia augusta & Flavonoids & Antioxidant & {$[35,36,37]$} \\
\hline 7 & Chulupa Passiflora maliformis & $\begin{array}{l}\text { Anthocyanin } \\
\text { Flavonoids }\end{array}$ & $\begin{array}{c}\text { Antioxidant } \\
\text { Antimicrobial }\end{array}$ & {$[38]$} \\
\hline 8 & Coriander Coriandrum sativum & Flavonoids & Antioxidant & {$[39,40]$} \\
\hline 9 & Copaíba Copaifera langsdorffii & Flavonoids & $\begin{array}{c}\text { Antimalarial } \\
\text { Gastro protective }\end{array}$ & {$[41,42,43]$} \\
\hline 10 & Curuba larga Passiflora mollissima & Flavonoids & Antioxidant & {$[44]$} \\
\hline 11 & Strawberry Fragaria vesca & Flavonoids & Anti-inflammatory & {$[45,46]$} \\
\hline 12 & Bean Phaseolus vulgaris & Anthocyanin & Antioxidant & {$[47,48]$} \\
\hline 13 & Sour guava $P$ sidium araca & Flavonoids & Antioxidant & {$[49,50]$} \\
\hline 14 & Sugar mango Mangifera indica & Phenols & Antioxidant & {$[51,52,53]$} \\
\hline 15 & Passion fruit Passiflora edulis & Phenols & Antioxidant & {$[54,55]$} \\
\hline 16 & Blackberry Rubus fruticosus & Flavonoids & Anti-inflammatory & {$[56,57]$} \\
\hline 17 & Tree tomato Cyphomandra betacea & Flavonoids & Antioxidant & {$[58,59]$} \\
\hline 18 & Grapefruit Citrus paradisi & Flavonoids & Anti-inflammatory & {$[60,56]$} \\
\hline 19 & Uchuva Physalis peruviana & Flavonoids & Antioxidant & {$[61,62,63,64,65]$} \\
\hline 20 & Grape Vitis vinifera & Flavonoids & Antiansiolitic & {$[66,67]$} \\
\hline 21 & Yacón Smallanthus sonchifolius & Flavonoids & Antidiabetic & {$[68,69]$} \\
\hline
\end{tabular}




\section{Applications and Contributions to Health}

\subsection{Nutritional Aspects and Benefits}

Polyphenols and flavonoids are found in fruit, vegetables, and other dietary products, such as wine, tea, chocolate, and coffee [2]. The types and contents consumed vary depending on source and its frequency of consumption. Regular coffee use in North America accounts for about $500-800 \mathrm{mg}$ of hydroxycinnamic acid consumption per day [2]. Different studies show that total individual flavonoid intake, from different products, is up to $20 \mathrm{mg}$ /day in the USA; while in the Netherlands, it can be higher than $70 \mathrm{mg} /$ day $[70,71,72,45]$.

The inclusion of the flavonoid catechin in the diet, consumed in dry seeds and tea, yields a $20 \%$ reduction in the incidence of disease [73]. In a study with around 5,000 volunteers given flavonoids from different foods including tea, the risk of myocardial infarction was inversely associated with flavonoid consumption [73,74]. Health benefits from polyphenol and flavonoid-rich diets are attributed mainly to their anti-obesity effects, and their antioxidant and anti-inflammatory activities [72].

Polyphenols act both directly and indirectly on adipose tissue, which interact specifically with pre-adipocytes, stem cells and immune system cells [72]. Catechins from green tea and flavonoids such as resveratrol and curcumin provide antioxidant and anti-inflammatory activities in obese individuals [72]. They offer health benefits, lowering body weight, cellular, and plasmatic lipids, and increasing the basal metabolic rate, energy expenditure, and insulin sensitivity [72]. A significant reduction in the incidence of coronary disease is associated with flavonoid consumption [75]; clinical studies suggest that prophylactic administration of these polyphenols reduces free radical production in reperfusion generated from bypass surgery in vascular replacement [12].

\subsection{Therapeutic Uses}

The antioxidant and anti-inflammatory actions of polyphenols and flavonoids have attracted attention for therapeutic use. An example of this is a study which evaluated flavonoids found in blackberries and strawberries against the action of anti-inflammatory drugs such as acetylsalicylic acid [45]. These flavonoids inhibited hyaluronidase, responsible for inflammatory processes [45]. Quercetin, a flavonoid with antiinflammatory and antioxidant activities found in several fruits, decreases the expression of claudine-2 in A549 lung adenocarcinoma cells [76]. These studies show that potential therapeutic targets of flavonoids could offer beneficial alternative therapies.

Another therapeutic activity of flavonoids is found in extracts and seeds of grapefruit; they exhibit bacteriocidal, fungicidal, and antiviral activities as well as being effective against the HIV virus in vitro [56]. Naringenin, found in this fruit, inhibits the replication of dengue virus in human monocytes infected with serotype-4 [77]. Naringenin also inhibits enzymes related to cytochrome P450 and the development of breast cancer cells [78,79].
Naringenin is thus a potential natural drug with several therapeutic targets.

Acai is a flavonoid rich tropical fruit and its polyphenols are efficient regulators of inflammation in obesity, and also feasible modulators of low grade chronic inflammatory factors [24]. Consumption of acai pulp has been shown to accentuate the expression of epidermal growth factor and plasminogen activator inhibitor-1 (PAI-1) in overweight women, leading to higher expression of PAI-1 protein and improving insulin resistance. In this study, the women also reported lower blood pressure levels [24].

Olive oil and tomato are important sources of polyphenols. The inclusion of rich polyphenols in virgin olive oil and tomato has yielded positive effects on cardiovascular disease risk factors [80]. Consumption of tomato sauce enriched with refined olive oil decreased the total cholesterol in plasma. Triglycerides and various inflammatory cellular and plasma biomarkers were also diminished, while HDL cholesterol levels increased [80]. These polyphenols also increased the proportion of intestinal bacteria coated with immunoglobulin A (IgA) [80]. An enhancement of the activity of intestinalassociated lymphoid tissue was observed, IgA being the most abundant immunoglobulin in the intestinal mucosa (80-90\%) and playing a very important role as the first defense against toxins and pathogen colonization and invasion [80].

Cacao, also called cocoa, is a flavanol rich product. It reduces vascular inflammation [81]. A brain imaging study showed that after the consumption of flavanol-rich cocoa there was an increase in cortical blood flow [81]. This result is of particular relevance when considering possible therapies to increase cerebrovascular function and to influence different brain regions for neurogenesis. Flavonoids in cocoa also increase cerebral blood flow and protect neurons against inflammatory processes that lead to cell injury [81].

Flavonoids in different dietary products offer anxiolytic or anticonvulsant effects; they can interact with gamma amino butyric acid (GABA) receptors and produce sedative action [82]. Studies have shown that quercetin and isoquercetin have anticonvulsive effects in experimental epilepsy models $[82,83]$. Research has demonstrated that flavonoids are able to exert antiepileptic activity by modulating the GABA receptor chloride ion channel, because they are structurally similar to benzodiazepines [83].

\section{Discussion and Conclusion}

The variety and functionality of polyphenols and flavonoids explains their multiple nutritional and therapeutic values to humans. Their functional groups and numerous subclasses allow them to participate in several biochemical pathways and to provide different biological activities [7,9]. One of the most studied properties of polyphenols and flavonoids is their antioxidant activity $[1,5,6,18]$. They also possess anti-inflammatory, antiviral, bactericidal and fungicidal activities. Colombian fruits and vegetables are a source of several polyphenols and flavonoids. A wider variety of tropical and Amazonian products could become important providers of these phytochemicals in the future. 
Some polyphenols may provide alternatives to commonly used drugs. Several diseases are inhibited by specific flavonoids. These natural compounds have been used in the treatment of viruses, cancerous cells, and lipid disorders, and for the improvement of the nervous system and cerebrovascular functions [45,76,80,81]. Flavonoids, in comparison to commonly used drugs, can act at different points of biochemical pathways. New tropical and Amazonian fruits should be evaluated, focusing on their total polyphenol content in order to widen the possibilities for therapeutic alternatives for the treatment of current and future diseases.

\section{References}

[1] Kumar, S., Pandey, A. K. 2013. "Chemistry and Biological Activities of Flavonoids: An Overview," The Scientific World Journal vol. 2013, 2013, p. e162750.

[2] Martin, D.A., Bolling, B.W. 2015. "A review of the efficacy of dietary polyphenols in experimental models of inflammatory bowel diseases," Food \& Function, 6 (6): 1773-1786.

[3] Galeano G., P., Cuellar A., L., Schinella, G. 2012. "Influencia Del Procesamiento Del Grano De Copoazu (theobroma Grandiflorum), Sobre La Actividad Antioxidante Y El Contenido Fenolico," Vitae, 19 (1): S285-S287.

[4] Rodrìguez, C.A., Chagas, P.C., Chagas, E.A., Pérez, C.P.R., Flores, W.M.P., Tamani, E.R., Tuesta, L.V., Vásquez, M.J. 2015. "Efecto del ácido indolbutírico y tipo de estacas en el enraizamiento de copoazú en cámaras de subirrigación," Ciencia Amazónica, Iquitos, 5 (2): 104-109.

[5] Scalbert, A., Johnson, I.T., Saltmarsh, M. 2005. "Polyphenols: antioxidants and beyond," American Journal of Clinical Nutrition, 81 (1): 215S-217S.

[6] Plaza, M., Pozzo, T., Liu, J., Gulshan Ara, K.Z., Turner, C., Nordberg Karlsson, E. 2014. "Substituent Effects on in Vitro Antioxidizing Properties, Stability, and Solubility in Flavonoids," Journal of Agricultural and Food Chemistry, 62 (15): 3321-3333.

[7] Siddiqi, R., Naz, S., Sayeed, S.A., Ishteyaque, S., Haider, M.S., Tarar, O.M., Jamil, K. 2013. "Antioxidant Potential of the Polyphenolics in Grewia asiatica, Eugenia jambolana and Carissa carandas," The Journal of Agricultural Science, 5 (3): 217-223.

[8] Tsao, R. 2010. "Chemistry and Biochemistry of Dietary Polyphenols," Nutrients, 2 (12): 1231-1246.

[9] Murcia P., M.A., Parras, P., Jiménez, A.M., Vera, A.M., MartínezTomé, M. 2008. "Polifenoles y flavonoides: su importancia en la prevención de enfermedades," Nutrición y Salud, 3: 121-142.

[10] Porras-Loaiza, A.P., López-Malo, A. 2009. "Importancia de los grupos fenólicos en alimentos," Temas Selectos de Ingeniería de Alimentos, 3 (1): 121-134.

[11] Eghbaliferiz, S., Iranshahi, M. 2016. "Prooxidant Activity of Polyphenols, Flavonoids, Anthocyanins and Carotenoids: Updated Review of Mechanisms and Catalyzing Metals," Phytotherapy Research, 30 (9): 1379-1391.

[12] Martínez-Flórez, S., González-Gallego, J., Tuñón, J.M.C. y M. ${ }^{a}$ J. 2002. "Los flavonoides: propiedades y acciones antioxidantes," Nutrición Hospitalaria, 17 (6): 271-278.

[13] Carocho, M., Ferreira, I.C.F.R. 2013. "A review on antioxidants, prooxidants and related controversy: Natural and synthetic compounds, screening and analysis methodologies and future perspectives," Food Chemical Toxicology, 51: 15-25.

[14] Beta, T., Nam, S., Dexter, J.E., Sapirstein, H.D. 2005. "Phenolic Content and Antioxidant Activity of Pearled Wheat and RollerMilled Fractions," Cereal Chemistry Journal, 82 (4): 390-393.

[15] Shahidi, F., Ambigaipalan, P. 2015. "Phenolics and polyphenolics in foods, beverages and spices: Antioxidant activity and health effects - A review," Journal of Functional Foods, 18 (Part B): 820-897.

[16] Zhang, Y.-J., Gan, R.-Y., Li, S., Zhou, Y., Li, A.-N., Xu, D.-P., Li, H. -B. 2015. "Antioxidant Phytochemicals for the Prevention and Treatment of Chronic Diseases," Molecules, 20 (12): 21138-21156.

[17] Henderson, M.C., Miranda, C.L., Stevens, J.F., Deinzer, M.L., Buhler, D.R. 2000. "In vitro inhibition of human P450 enzymes by prenylated flavonoids from hops, Humulus lupulus," Xenobiotica, 30 (3): 235-251.

[18] Moreno, E., Ortiz, B.L., Restrepo, L.P. 2014. “Total phenolic content and antioxidant activity of pulp extracts of six tropical fruits," Revista Colombiana de Química, 43 (3): 41-48.

[19] Zapata, S., Piedrahita, A.M., Rojano, B. 2014. "Capacidad atrapadora de radicales oxígeno (ORAC) y fenoles totales de frutas y hortalizas de Colombia," Perspectivas En Nutrición Humana, 16 (1): 25-36.

[20] Mateus-Cagua, D., C, M.E.A., Orduz-Rodríguez, J.O. 2015. “E1 cultivo de carambolo (Averrhoa carambola L.) y su comportamiento en el piedemonte del Meta (Colombia). Una revisión," Revista Colombiana de Ciencias Hortícolas, 9 (1): 135 148.

[21] Saghir, S.A.M. 2013. "Star fruit (Averrhoa carambola L.): From traditional uses to pharmacological activities," Boletín Latinoamericano y del Caribe de Plantas Medicinales $y$ Aromáticas, 12 (3): 209-219.

[22] Domínguez, Beatriz, Martínez-Morales, A., Alia-Tejacal, I. 2010. "Caracterización de la maduración en ecotipos de zapote mamey (Pouteria sapota)," Revista Iberoamericana de Tecnología y Postcosecha, 11 (2): 122-129.

[23] Alia-Tejacal, I., Soto-Hernández, R.M., Colinas-León, M.T., Martínez-Damián. 2005. "Análisis preeliminar de carotenoides y compuestos fenólicos en frutos de zapote mamey (Pouteria sapota (Jacq.) H.E. Moore \& Stearn)," Revista Chapingo Serie Horticultura, 11 (2): 225-231.

[24] de Sousa Pereira, I., Moreira Cançado Mascarenhas Pontes, T.C., Lima Vieira, R.A., de Freitas Folly, G.A., Cacilda Silva, F., Pereira de Oliveira, F.L., Ferreira do Amaral, J., Nascimento de Freitas, R., Pinheiro Volp, A.C. 2015. "The consumption of acai pulp changes the concentrations of plasminogen activator inhibitor-1 and epidermal growth factor (egf) in apparently healthy women," Nutrición Hospitalaria, 32 (2): 931-945.

[25] Isaza Aranguren, C., Galeano, G.G., González, R. 2014. “Manejo actual del asaí (euterpe precatoria mart.) para la producción de frutos en el sur de la amazonia colombiana," Colombia Forestal, 17 (1): 77-99.

[26] Sarmento Abrantes, J.D., Dantas de Morais, P.L., Irael De Souza, F., Ramos da Costa, L., de Assis Melo, de A. 2015. "Bioactive compounds and antioxidant activity of Ximenia americana coming from different collection sites," Archivos Latinoamericanos Nutrición, 65 (4): 263-271.

[27] Dias, A.L.S., Rozet, E., Larondelle, Y., Hubert, P., Rogez, H., Quetin-Leclercq, J. 2013. "Development and validation of an UHPLC-LTQ-Orbitrap MS method for non-anthocyanin flavonoids quantification in Euterpe oleracea juice," Analytical and Bioanalytical Chemistry, 405 (28): 9235-9249.

[28] Rojano, B.A., Zapata Vahos, Z., Alzate Arbeláez, A., Mosquera Martínez, M., Cortés Correa, C., Gamboa Carvajal, L. 2011. "Polifenoles y Actividad Antioxidante del Fruto Liofilizado de Palma Naidi (Açai Colombiano) (Euterpe oleracea Mart)," Revista Facultad Nacional de Agronomía Medellín, 64 (2): 6213-6220.

[29] Heras, I., Alvis, A., Arrazola, G. 2013. "Optimización del Proceso de Extracción de Antocianinas y Evaluación de la Capacidad Antioxidante de Berenjena (Solana melonera L.)," Información Tecnológica, 24 (5): 93-102.

[30] Aramendiz-Tatis, H., Cardona-Ayala, C., De Oro, R. 2010. "Periodo de interferencia de arvenses en el cultivo de berenjena (Solanum melongena L.) Hermes 1, 3, Carlos 1 y," Agronomía Colombiana, 28 (1): 81-88.

[31] González-Mendoza, D., Troncoso-Rojas, R., Ceceña Durán, C., Grimaldo-Juárez, O., Zamora-Bustillo, R., Ruiz-Sánchez, E. 2015. "Compuestos fenólicos y capacidad antioxidante presentes en tres variedades de berenjena cultivadas en el valle de Mexicali, Baja California," Idesia Arica, 33 (3): 17-21.

[32] Salamanca G, G., T, O., Patricia, M., Montoya, L.M. 2010. "Elaboración de una bebida funcional de alto valor biológico a base de borojo (Borojoa patinoi Cuatrec)," Revista Chilena de Nutrición, 37 (1): 87-96.

[33] Soleto D., I., Casas F., N., and M, G. 2010. "Borojó (Borojoa patinoi): fuente de polifenoles con actividad antimicrobiana," Vitae, 17 (3): 329-336.

[34] Hurtado, N.H., Pérez, M. 2014. "Identificación, Estabilidad y Actividad Antioxidante de las Antocianinas Aisladas de la Cáscara del Fruto de Capulí (Prunus serótina spp capuli (Cav) Mc. Vaug Cav)," Información Tecnológica, 25 (4): 131-140. 
[35] García-Torres, D.E., Sotero Solís, V., Mancini, D. a. P., Torres, R.P., Mancini-Filho, J. 2009. "Actividad antioxidante de los extractos del chopé (Gustavia augusta L.)," Revista Sociedad Quimica del Perú, 75 (3): 374-381.

[36] García, D., Sotero, V., Mancini, D., Pavan Torres, R., Mancini Filho, J. 2011. "Evaluación de la actividad antioxidante 'In vivo' de tres frutos de la amazonía: Gustavia augusta L., Grias neuberthii Macbr y Theobroma bicolor," Revista Sociedad Química del Perú, 77 (1): 44-55.

[37] Mosquera Perea, D.E., Martínez Guardia, M., Medina, H.H., Ninestroza, L.I.H. 2013. "Caracterizacion bromatologica de especies y subproductos vegetales en el tropico humedo de Colombia," Acta Agronómica, 62 (4): 326-332.

[38] Sabogal Palma, A.C., Chávez Marín, J., Oliveros Gómez, D.F., Murillo Perea, E., Arteaga, J.J. 2016. "Funcionalidades biológicas de passiflora maliformis del sur macizo colombiano," Bioagro, 28 (1): 3-12.

[39] Ceballos, A.M., Giraldo, G.I. 2011. "El cilantro (Coriandrum sativum L.) como fuente potencial de antioxidantes naturales.," Vector, 6: 85-93.

[40] Banda S., L., Fuentes, C.L., Chaves, B. 2011. "Producción de semilla de cilantro (Coriandrum sativum L.) bajo la incidencia de malezas y Alternaria Nees," Revista Colombiana de Ciencias Horticolas, 5 (2): 279-294.

[41] Batista, Â.G., Ferrari, A.S., da Cunha, D.C., da Silva, J.K., Cazarin, C.B.B., Correa, L.C., Prado, M.A., Carvalho-Silva, L.B. de, Esteves, E.A., Maróstica Júnior, M.R. 2016. "Polyphenols, antioxidants, and antimutagenic effects of Copaifera langsdorffii fruit," Food Chemistry, 197 (Part B): 1153-1159.

[42] Herrera Valencia, W., Hernández Londoño, C., Ramírez, Y. 2010. "Plantas oleaginosas del Caquetá, Amazonia colombiana," Ingeniería Amazónica, 3 (1): 28-39.

[43] Lemos, M., Santin, J.R., Mizuno, C.S., Boeing, T., Sousa, J.P.B. de, Nanayakkara, D., Bastos, J.K., Andrade, S.F. de, Lemos, M., Santin, J.R., et al. 2015. "Copaifera langsdorffii: evaluation of potential gastroprotective of extract and isolated compounds obtained from leaves," Revista Brasileira de Farmacognosia, 25 (3): $238-245$

[44] Chaparro R., D.C., Maldonado C., M.E., Camila Franco L., M., Amparo Urango M., L. 2015. "Características nutricionales y antioxidantes de la fruta curuba larga (Passiflora mollissima Bailey),"Perspectivas En Nutrición Humana, 6 (2): 203-212.

[45] Araujo, L., Buitrago, D., Marquina, M.A., Morales, N., Mendez, G., Pernía, T., Sosa, M. 2002. "Comparación de la actividad antiinflammatoria de los polifenoles presentes en las frutas; Mora (Rubus futicosus B.), Fresa (Fragraria vesca L.), Grapefruit (Citrus paradasi M)," Revista de la Facultad de Farmacia, 44: 64-69.

[46] Angulo C., A.F., Rosero R., R.A., González I., M.S. 2012 "Estudio etnobotánico de las plantas medicinales utilizadas por los habitantes del corregimiento de Genoy, Municipio de Pasto, Colombia Ethnobotanical study of medicinal plants used by the inhabitants of the village of Genoy, Municipality of Pasto, Colombia," Universidad y Salud, 14 (2): 168-185.

[47] Puertas-Mejía, M.A., Ríos-Yepes, Y., Rojano, B.A. 2013. "Determinación de antocianinas mediante extracción asistida por radiación de microondas en frijol (Phaseolus vulgaris L.) de alto consumo en Antioquia-Colombia," Revista Cubana de Plantas Medicinales, 18 (2): 288-297.

[48] Álvarez Salas, L.M., Turbay Ceballos, S.T. 2009. "El fríjol petaco (phaseolus coccineus) y la maravilla (phaedranassa sp.): aspectos etnobotánicos de dos plantas alimenticias de origen americano en el oriente antioqueño, Colombia," Agroalimentaria, 15 (29): 101-113.

[49] Zapata, K., Cortes, F.B., Rojano, B.A. 2013. "Polifenoles y Actividad Antioxidante del Fruto de Guayaba Agria (Psidium araca)," Información Tecnológica, 24 (5): 103-112.

[50] Lara Mantilla, C., Mendoza F, C.A., Oviedo Zumaqué, L.E. 2010. "Productividad y selectividad del medio de cultivo a partir de guayaba agria (Psidium araca) en el crecimiento de levaduras nativas del género Candida sp," Revista Colombiana de Biotecnología, 12 (2): 116-123.

[51] Corrales-Bernal, A., Maldonado, M.E., Urango, L.A., Franco, M.C., Rojano, B.A. 2014. "Mango de azúcar (Mangifera indica), variedad de Colombia: características antioxidantes, nutricionales y sensoriales," Revista Chilena de Nutrición, 41 (3): 312-318.

[52] Corrales-Bernal, A., Urango, L.A., Rojano, B., Maldonado, M.E. 2014. "In vitro and in vivo effects of mango pulp (Mangifera indica cv. Azucar) in colon carcinogenesis," Archivos Latinoamericanos de Nutrición, 64 (1): 16-23.

[53] Arrazola P., G., Rojano, B.A., Díaz D., A. 2013. "The antioxidan capacity of five mango cultivars (Mangifera indica L.) and evaluation of its performance in a food matrix," Revista Colombiana de Ciencias Horticolas, 7 (2): 161-172.

[54] Pardo Jumbo, A.N. 2015. "Evaluación de la capacidad antioxidante y compuesto fenólicos en la pulpa de la maracúya (Passiflora edulis)," Universidad Técnica de Machala, Ecuador.

[55] Gobernación del Huila. 2006. "Manual tecnico del cultivo de maracuya (passiflora edulis L) en el departamento del Huila." Secretaría Técnica, Departamento del Huila, Colombia

[56] Morales, N., Marquina, M.A., Pernía, T., Buitrago, D., Corao, G., Sosa, M., Araujo, L. 2002. "Comparación de la actividad antiviral de polifenoles presentes en las frutas; mora (Rubus fruticosus B.), Grapefruit (Citrus paradisi M.) y fresa (Fragaria vesca L.)," Revista de la Facultad de Farmacia, 44: 43-46.

[57] Cancino-Escalante, G. O., Sánchez-Montaño, L. R., QuevedoGarcía, E., Díaz-Carvajal, C. 2011. "Caracterización fenotípica de accesiones de especies de Rubus L. de los municipios de Pamplona y Chitagá, región Nororiental de Colombia," Universitas Scientarium, 16 (3): 219-233.

[58] Torres, A. 2012. "Caracterización física, química y compuestos bioactivos de pulpa madura de tomate de árbol (Cyphomandra betacea) (Cav.) Sendtn.," Archivos Latinoamericanos de Nutrición, 62 (4): 381-388.

[59] Garzón Gutiérrez, G., Cortés, C.A., Camacho-Tamayo, J.H. 2010 "Spatial variability of some chemical properties in a entisol," Revista UDCA Actualidad y Divulgación Científica, 13 (1): 87-95.

[60] Ordúz Rodríguez, O. 2012. La Ecofisiología de los Cítricos en el Trópico: El Caso del Piedemonte Llanero de Colombia. Corporación Universitaria Lasallista, Colombia.

[61] Corrales-Bernal, A., Vergara, A.I., Rojano, B., Yahia, E., Maldonado, M.E. 2015. "Características nutricionales y antioxidantes de la uchuva colombiana (Physalys peruviana L.) en tres estadios de su maduración," Archivos Latinoamericanos de Nutrición, 65 (4): 254-262.

[62] Criollo, H., Lagos, T.C., Fischer, G., Mora, L., Zamudio, Lady 2014. "Behavior of three cape gooseberry (Physalis peruviana L.) genotypes under different pruning systems," Revista Colombiana de Ciencias Horticolas, 8 (1): 34-43.

[63] Cortés Díaz, G.M., Prieto Suarez, G.A., Rozo Nuñéz, W.E. 2015 "Bromatological and Physicochemical Characterization of Physalis peruviana L., and its Potential as a Nutraceutic Food," Ciencia En Desarrollo, 6 (1): 87-97.

[64] Marin A., Z.T., Cortés R., M., Montoya C., O.I. 2010. "Uchuva (physalis peruviana 1.) ecotipo Colombia, mínimamente procesada inoculada con la cepa nativa lactobacillus plantarum LPBM10 mediante la técnica de impregnación a vacío," Revista Chilena de Nutrición, 37 (4): 461-472.

[65] Lopez, J., Vega-Gálvez, A., Torres, M.J., Lemus-Mondaca, R. Quispe-Fuentes, I., Di Scala, K. 2013. "Effect of dehydration temperature on physico-chemical properties and antioxidant capacity of goldenberry (Physalis peruviana L.)," Chilean Journal of Agricultural Research, 73 (3): 293-300.

[66] Soares, F.A.A., Dalla Corte, C.L., Andrade, E.R., Marina, R., González, P., Barrio, J.P. 2014. "El mosto de uva tinta como protector frente a las alteraciones agudas de movilidad, ansiedad y comportamiento ingestivo inducidas por rayos X en ratones," Nutrición Hospitalaria, 29 (4): 812-821.

[67] Gobernación del Huila, 2006. "Manual técnico del cultivo de la uva en el Huila." Secretaría Técnica, Departamento del Huila, Colombia.

[68] Arnao, I., Seminario, J., Cisneros, R., Trabucco, J. 2011 "Potencial antioxidante de 10 accesiones de yacón, Smallanthus sonchifolius (Poepp. \& Endl.) H. Robinson, procedentes de Cajamarca - Perú," Anales de la Facultad de Medicina, 72 (4): 239-243.

[69] Mendoza Meza, M., Loza Rosas, L. 2014. "Actividad inhibitoria alfa-amilasa y fenoles totales en extractos etanólicos de hojas de Smallanthus sonchifolius (yacón)," Revista Cubana de Plantas Medicinales, 19 (4): 310-318.

[70] Ksiezak-Reding, H., Ho, L., Santa-Maria, I., Diaz-Ruiz, C., Wang, J., Pasinetti, G.M. 2012. "Ultrastructural alterations of Alzheimer's disease paired helical filaments by grape seed-derived polyphenols," Neurobiology of Aging, 33 (7): 1427-1439. 
[71] Georgiev, V., Ananga, A., Tsolova, V. 2014. "Recent Advances and Uses of Grape Flavonoids as Nutraceuticals," Nutrients, 6 (1): 391-415.

[72] Wang, S., Moustaid-Moussa, N., Chen, L., Mo, H., Shastri, A., Su, R., Bapat, P., Kwun, I., Shen, C.-L. 2014. "Novel insights of dietary polyphenols and obesity," The Journal of Nutritional Biochemistry, 25 (1): 1-18.

[73] Arts, I.C., Hollman, P.C., Feskens, E.J., Mesquita, H.B.B. de, Kromhout, D. 2001. "Catechin intake might explain the inverse relation between tea consumption and ischemic heart disease: the Zutphen Elderly Study," American Journal of Clinical Nutrition., 74 (2): 227-232.

[74] Geleijnse, J.M., Launer, L.J., Kuip, D.A. van der, Hofman, A., Witteman, J.C. 2002. "Inverse association of tea and flavonoid intakes with incident myocardial infarction: the Rotterdam Study," American Journal of Clinical Nutrition, 75 (5): 880-886

[75] Keli, S.O., Hertog, M.L., Feskens, .EM., Kromhout, D. 1996. "Dietary flavonoids, antioxidant vitamins, and incidence of stroke: The zutphen study," Archives of Internal Medicine., 156 (6): 637-642.

[76] Sonoki, H., Sato, T., Endo, S., Matsunaga, T., Yamaguchi, M. Yamazaki, Y., Sugatani, J., Ikari, A. 2015. "Quercetin Decreases Claudin-2 Expression Mediated by Up-Regulation of microRNA miR-16 in Lung Adenocarcinoma A549 Cells," Nutrients, 7 (6): 4578-4592.

[77] Frabasile, S., Koishi, A.C., Kuczera, D., Silveira, G.F., Verri, W.A., Duarte dos Santos, C.N., Bordignon, J. 2017. "The citrus flavanone naringenin impairs dengue virus replication in human cells," Scientific Reports, 7: 41864.

[78] Fuhr, U., Kummert, A.L. 1995. "The fate of naringin in humans: a key to grapefruit juice-drug interactions?," Clinical Pharmacology and Therapentics., 58 (4): 365-373.

[79] So, F.V., Guthrie, N., Chambers, A.F., Moussa, M., Carroll, K.K. 1996. "Inhibition of human breast cancer cell proliferation and delay of mammary tumorigenesis by flavonoids and citrus juices," Nutrition and Cancer, 26 (2): 167-181.

[80] Ramiro-Puig, E., Pérez Cano, F.J., Castellote, C., Franch, A., Castell, M. 2008. "El intestino: pieza clave del sistema inmunitario," Revista Española de Enfermedades Digestivas, 100 (1): 29-34.

[81] Lamport, D.J., Pal, D., Moutsiana, C., Field, D.T., Williams, C.M., Spencer, J.P.E., Butler, L.T. 2015. "The effect of flavanol-rich cocoa on cerebral perfusion in healthy older adults during conscious resting state: a placebo controlled, crossover, acute trial," Psychopharmacology (Berl.), 232 (17): 3227-3234

[82] Diniz, T.C., Silva, J.C., de Lima-Saraiva, S.R.G., Ribeiro, F.P.R. de A., Pacheco, A.G.M., de Freitas, R.M., Quintans-Júnior, L.J., Quintans, J. de S.S., Mendes, R.L., Almeida, J.R.G. da S. 2015. "The Role of Flavonoids on Oxidative Stress in Epilepsy," Oxidative Medicine and Cellular Longevity, 2015, Article ID 171756, 9 pages.

[83] Choudhary, N., Bijjem, K.R.V., Kalia, A.N. 2011. "Antiepileptic potential of flavonoids fraction from the leaves of Anisomeles malabarica," Journal of Ethnopharmacology, 135 (2): 238-242. 